\title{
The elasticity of labor supply at the establishment level
}

\author{
TORBERG FALCH \\ Department of Economics, Norwegian University of Science and Technology, \\ N-7491 Trondheim, Norway \\ E-Mail: Torberg.Falch@svt.ntnu.no \\ November 2008
}

\begin{abstract}
Monopsonistic wage-setting power requires that the supply of labor directed toward individual establishments is upward sloping. This paper utilizes institutional features to identify the supply curve. The elasticity of labor supply is estimated using data for the Norwegian teacher labor market in a period where the only variation in the wage level was determined centrally, and with information on whether there is excess demand or not at the school level. In fixed effects models, the supply elasticity faced by individual schools is estimated to about 1.5, and is in the range 1.0-1.9 in different model specification.
\end{abstract}

Keywords: Labor supply elasticity; teacher supply; monopsony

JEL codes: C23; C24; I29; J22

\footnotetext{
* This paper is part of a project funded by the Norwegian Research Council. The Ministry of Education and Research and the government educational offices in Nordland, Troms and Finnmark are acknowledged for kindly making school-level data available for this analysis. The rest of the data are obtained from the Norwegian Social Science Data Service. Comments from William Boal, Paul Heaton, Kåre Johansen, Alan Manning, Bjarne Strøm, Jean-Pierre Urbain, and participants at the congress of the European Economic Association, the conference of the European Association of Labour Economists, the Nordic Econometric Meeting, and the Monopsony in the Labor Market Conference in Sundance Resort, Utah, are gratefully acknowledged. The author bears the full responsibility for the analysis and the conclusions that are drawn.
} 


\section{Introduction}

Recently there has been increasing interest in models where firms have monopsonistic wagesetting power in the labor market. Several empirical labor market phenomena, for example wage dispersion across identical workers and nonnegative employment effects of minimum wages, are hard to explain by perfectly competitive models but easily explained by frictions in the labor market. Imperfect information, mobility costs, and heterogeneous preferences over nonwage attributes that make employers imperfect substitutes are all plausible causes of imperfect competition. It may be argued that the conditions for perfect competition are violated to a greater extent in the labor market than in most product markets because it is relatively costly to change one's job.

Wage-setting power of firms requires that the labor supply is not perfectly elastic at the firm level. While several empirical regularities can be explained by imperfect competition, rejection of the hypothesis of horizontal labor supply is the direct test of the relevance of monopsony models. There are, however, inherent difficulties in estimating the structural parameters of the labor supply function because one typically does not have good instruments for wages at the firm level.

The lack of good instruments for wages makes it attractive to utilize specific institutional settings and experiments with exogenous wage changes to identify the supply curve. Some professional labor markets with centrally determined wages may have this property. Even though individual establishments cannot influence their wage under centralized wage setting, workers should react to wage differences in the same way as under firm-level wage setting. Since supply is determined by individual behavior, empirical regularities from specific labor markets might be generalized.

The present paper exploits specific characteristics of the Norwegian teacher labor market. During a period of more than 40 years, wages were solely determined by central wage bargaining. With one exception, the only sources of wage variation across teachers have been teaching experience and the amount of formal education. The exception, in which teachers in individual schools with large teacher shortages in the past received about 10 percent higher wage, is exploited in a school fixed effects framework. To identify labor supply, it is essential to observe the supply in addition to the wage variation. When wages are centrally determined, 
one would expect excess demand in some establishments and excess supply in others. It is possible to observe excess demand in our data because of a clear-cut rule regarding the appointment of teachers. In Norway, individuals without a teaching credential can be employed only when it is impossible to recruit certified teachers to vacant teaching positions. Employment of individuals without a teaching credential reflects excess demand, and teacher supply is then given by the number of certified teachers.

The next section presents relevant empirical literature. Section 3 explores the institutional setting more closely, and some theoretical considerations and the data are discussed in sections 4 and 5, respectively. The empirical findings are reported in Section 6. Several sensitivity tests are undertaken, and I also test whether the supply elasticity is heterogeneous across localities. Section 7 provides concluding comments.

\section{Previous empirical studies on establishment level labor supply}

The first study using data at the establishment level in order to estimate the labor supply elasticity appears to be Sullivan (1989). He estimates the supply elasticity of nurses directed toward individual hospitals to be in the range 1.3-3.8, identifying demand shifts by assuming an exogenous level of hospital caseload. Staiger et al. (1999), however, argue that the caseload was endogenous in the period studied by Sullivan (1989). They utilize a legislative increase in the wage for nurses at Veterans Administration (VA) hospitals. VA hospitals paid nurses based on a national scale until 1991, when a system where wages are based on local surveys was introduced. The size of the wage increase was related to local relative wages. The wage rose in about two-thirds of the VA hospitals, while at the remaining hospitals, which paid at or above the wage level in the surrounding hospitals, the wage did not change. Their estimate of the supply elasticity is around 0.1 and insignificantly different from zero, which implies large monopsony power.

When wages are not instrumented it is essential not only to have exogenous wages, but also to distinguish between labor demand and labor supply. Staiger et al. (1999) argue that the employment of nurses is likely to be 'supply constrained' because of nearly continuous reports of shortages of nurses since World War II. However, this is aggregated information, and variations in for example working conditions and workload may yield demand- 
constrained employment at hospitals initially paying a lower wage than surrounding hospitals. Their empirical result is in fact close to some studies of the effect of minimum wages, see for example Card and Krueger (2000) and Neumark and Wascher (2000). As Boal and Ransom (1997) and Dickens et al. (1999) clearly show, the effect of an increase in the minimum wage on employment is nonlinear because more firms become 'demand constrained' as the minimum wage increases. Dickens et al. (1999) estimate an average elasticity of the minimum wage with respect to UK employment of about 0.3 , but the elasticity seems to be above 2 in the industries with the lowest minimum wage.

Some older papers attempt to estimate firm-level labor supply on regional data. Nelson (1973) argues that a population density measure can be used for identification of labor supply and reports large elasticities for most US states. Boal (1995) argues that it is important to have data with a panel structure in order to control for unobserved factors such as remote location and other potential sources of compensating differentials. Using data from US coal mining in the first decades of the 20th century, Boal (1995) finds the labor supply elasticity to be in the range $1.9-6.8$ in the short run and infinite in the long run.

The labor supply elasticity must be related to how sensitive worker turnover is to the wage level. Regarding teachers, Ransom and Sims (2008) use this insight and calculate the labor supply elasticity in Missouri to 3.5 under specific steady state conditions. Another stream of literature has interpreted the observed positive relationship between wages and employer size as an indication of inelastic labor supply, see for example Green et al. (1996). However, Manning (2003) shows that the quantitative relationship between employment and wages depends crucially on whether wages are regressed on employment or the other way around, and indicates that the reason is measurement error. He concludes that even though it is reasonable to interpret this relationship as evidence of upward sloping supply curves, such regressions 'are just not very informative' on the supply elasticity (Manning 2003, p. 95).

\section{A quasi-natural experiment}

Wage determination of teachers is highly centralized, with basically the same wage at each school in several European countries such as France, Germany, Italy, and the UK. In Norway, the wage of an individual teacher was solely determined by central wage bargaining up to and 
including the school year 2000-01. ${ }^{1}$ With only one exception, the wage varied across teachers only with respect to their education level and teaching experience. The exception was teachers at schools located in one of the three northernmost counties (out of a total of 19 counties in the country) with particular recruitment problems. The school districts had no influence on which schools were eligible for a higher wage and the selection had no financial implications for them.

I use the term experimental school for schools at which teachers received a wage premium at least once during the empirical period of the present paper. Three different systems to reduce teacher shortages have existed. In 1993-94 to 1995-96, teachers at schools with teacher shortages in the preceding school year exceeding 20 percent received a wage premium in nominal terms, which implies that the percentage wage premium varied with the initial wage. For schools with at least 30 percent shortages, the mean wage premium was about 10 percent. For schools with 20-30 percent shortages, the rules differed regionally. In the southern part of the relevant counties, the teacher wage premium was the same as for schools with more than 30 percent teacher shortages, while in the northern part the wage premium was only half as large. ${ }^{2}$

The system changed slightly for the school years 1996-97 and 1997-98. Then only teachers at schools with teacher shortages in the preceding school year exceeding 30 percent were eligible for a higher wage. Thus, fewer schools had a wage premium in this period as illustrated by School A in Table 1. School A was included (IN) in the first system, but not included (NIN) in the second system. Within the last system, continuing to the school year 2002-03, teachers at schools with teacher shortages during the four previous school years exceeding 20 percent on average received a wage premium, and the wage premium was equal across all included schools. ${ }^{3}$

Because increased wages are expected to raise labor supply, schools with teacher shortages marginally above the criterion for paying higher wages are expected to increase employment

\footnotetext{
${ }^{1}$ Some very limited local wage flexibility was introduced in 2001, and wage setting was further decentralized from 2004.

${ }^{2}$ The schools with the lowest wage premium are located in areas with a lower national income tax rate.

${ }^{3}$ Up to $1997-98$, the teachers could choose between the wage premium described and one year of study at a college with full pay. In the latter case, they had to commit themselves to work at the school for the following five years. Those choosing college obviously considered the benefit from a year of study to be larger than the wage premium. Thus, using the wage premium as the benefit of being employed at an IN school may underestimate the true benefit.
} 
of certified teachers such that the school is not eligible for a higher wage the next school year. This is illustrated by School B in Table 1. School B was an IN school in 1993-94, but not the following years. In this case, the teachers at the school in 1993-94 who stayed there kept their wage premium as long as the system was in place, while new teachers at the school did not get the wage premium. In such semi-included (SIN) schools, only quits and not hires are expected to differ from other schools. When a new system commences, and the school is still ineligible to be included in the system, none of the teachers receives the wage premium. Thus, if there are no serious teacher shortages at School B in 1994-95 to 1997-98, the school will be a SIN school in 1994-95 to 1995-96 and a NIN school in 1996-97 to 1997-98.

In summary, the experimental schools can be in three different states in a particular year; all teachers receive a wage premium, the incumbent teachers receive a wage premium, or none of the teachers receives a wage premium. Because factors explaining why some schools have consistently low teacher supply can be hard to observe, it is an attractive feature of the data that several schools changed status during the empirical period. It is therefore possible to analyze the within-school variation in teacher supply and wages in models where fixed school effects capture major systematic factors important for low supply.

To identify the elasticity of labor supply, the supply must be observed. The appointment rule of teachers in Norway is crucial in this regard, as discussed in Bonesrønning et al. (2005). First, the teachers are linked to the schools and not to the school districts. The school districts cannot influence the mobility of teachers with a permanent position, and likewise no other actors. Teachers leave for other schools, the bureaucracy, and the private sector, and they are recruited from the same places in addition to teacher colleges.

Second, the school districts have to appoint the best-qualified applicant to a vacant teacher position. If at least one certified teacher wants the vacant position, a certified teacher will fill the post. According to the school law, a person without the required qualifications to be certified as a teacher can only be employed if no certified teachers apply for a vacant teacher position. Furthermore, only certified teachers can be employed in permanent contracts. Noncertified teachers can only be hired on temporary contracts for up to one school year. In the subsequent year, the school must make the vacant position public again in order to get certified teachers to apply. According to national contracts, representatives of the teacher union must be informed prior to every hiring decision. In this way the union is able to closely 
monitor that the schools behave in accordance with the law, which has been a cornerstones in the teacher trade union policy. The rule is crucial for the definition of the teaching profession. Thus, observed shortages of certified teachers in a particular year reflects the state of the teacher labor market in that particular year, and since one observes whether there is excess demand or not, one can also observe for which schools the actual adjustment is on the supply curve. In that case, the supply is given by the number of certified teachers.

The situation is illustrated in Figure 1 which compares two schools with equal teacher demand, but different teacher supply. Given the centrally determined wage $\mathrm{W}^{*}$, school 1 (described by the teacher supply function $\mathrm{TS}^{1}$ ) has excess supply. The supply is greater than observed employment, and cannot be empirically identified. The employment of certified teachers at school 2 is determined by the size of the teacher supply, $\mathrm{S}^{2^{*}}$. Since the school has to employ noncertified teachers, the supply is empirically identified by $\mathrm{S}^{2^{*}}$. If teachers at school 2 are eligible to receive a higher wage, illustrated by $\mathrm{W}^{* *}$, teacher shortages are reduced if the supply curve is upward sloping as in the figure. Because the central government pays the wage premium, teacher shortages are reduced from $S^{*}-S^{2^{*}}$ to $S^{*}-S^{2^{* * *}}$. The excess demand can be eliminated if the wage rise is high or if the teacher supply is elastic.

The classification of IN schools was done by state representatives in the relevant counties. Up to $1997-98$, the classification was based on information collected for this purpose at the start of the school year (September 1), and from 1998-99 the classification was based on the national data collected in October that are used in the present paper. Because the criterion for a higher wage was previous teacher shortages, it has always been known in advance of the school year which schools that will pay a wage premium. From 1998-99 it has been explicit in the instructions that the classification of IN schools for the following school year should be done before March 1. For new positions made public before this date, the school districts had to pay the wage premium without compensation from the central government.

Since classification of IN schools is based on lagged information, there is no direct causal effect of current supply on whether there is a wage premium. However, if a school is able to reduce the number of certified teachers one year, the incumbent teachers may get a wage premium the next year. There are several reasons why this is not likely to be a serious problem in the present case. When I collected the data, the state representatives in the counties reported that they did not believe at all that the system was being manipulated. The 
appointment rules presented above are crucial in this regard. In addition, the criterion for IN schools varies over time and has been decided after the registration of teacher shortages. Both the changes in the system in 1995 and 1997 were decided in December, while the criterion is based on the shortages earlier in the fall. Thus, if it was any gaming of the system, the extent of the manipulation must be expected to vary over time. This issue will be considered in the empirical section of the paper by investigating the stability of the estimated supply elasticity.

\section{An applied theory of labor supply}

This section presents a simple mechanism that may yield an upward sloping labor supply curve directed toward establishments. Following McFadden's (1974) random utility function approach, assume that the well-behaved indirect utility function for worker $b$ in the set of workers B working at establishment $\mathrm{e}$ in the choice set $\mathrm{E}$ is given by

$\mathrm{u}_{\mathrm{e}}^{\mathrm{b}}=\mathrm{v}^{\mathrm{b}}\left(\mathrm{W}_{\mathrm{e}}, \mathrm{X}_{\mathrm{e}}\right)+\varepsilon_{\mathrm{e}}^{\mathrm{b}}$.

$\mathrm{W}_{\mathrm{e}}$ is the wage level and $\mathrm{X}_{\mathrm{e}}$ is a vector of characteristics of the establishment. ${ }^{4} \varepsilon_{\mathrm{e}}^{\mathrm{b}}$ is an independent error term with mean zero capturing that workers may have different unobserved tastes. Although deterministic for the individuals, the indirect utility function is random from an observer's point of view. In the present context, $\varepsilon^{b}{ }_{e}$ may also be interpreted as searching costs or other transaction costs. In models with costs of searching in the market, employers have some monopsony power (Mortensen, 1986). Frictions in the labor market may restrict the employees from fully responding to utility differences.

The probability that a worker prefers to work at establishment $i$ is $P_{i}^{b}=P\left(u_{i}^{b}=\max _{e \in E} u_{e}^{b}\right)$. McFadden $(1974,1984)$ shows that if the stochastic part of the random utility function has an extreme value distribution and the property of independence of irrelevant alternatives holds, this can be written as

$$
\mathrm{P}_{\mathrm{i}}^{\mathrm{b}}=\frac{\exp \left(\mathrm{v}^{\mathrm{b}}\left(\mathrm{W}_{\mathrm{e}}, \mathrm{X}_{\mathrm{e}}\right)\right)}{\sum_{\mathrm{e} \in \mathrm{E}} \exp \left(\mathrm{v}^{\mathrm{b}}\left(\mathrm{W}_{\mathrm{e}}, \mathrm{X}_{\mathrm{e}}\right)\right)} \text {. }
$$

\footnotetext{
${ }^{4}$ For teachers, a large literature finds that non-pecuniary factors such as student composition have an impact on quit rates and recruitment, see for example Falch and Strøm (2005) and Boyd et al. (2005).
} 
The supply directed toward a particular establishment is the sum of the probabilities for the individual workers, $\mathrm{S}_{\mathrm{i}}=\sum_{\mathrm{b} \in \mathrm{B}} \mathrm{P}_{\mathrm{i}}^{\mathrm{b}}$. In this general form, the supply to the individual establishment depends on characteristics of the individual workers. A meaningful aggregation requires some assumptions on the distribution of the utility functions. Denote the set of distinct different worker types $\mathrm{M}$, where $\mathrm{M}<\mathrm{E}$. Assume that only one worker type works in establishment $\mathrm{i}$. Then the supply can be written as

$$
\mathrm{S}_{\mathrm{i}}=\sum_{\mathrm{b} \in \mathrm{m}} \frac{\exp \left(\mathrm{v}^{\mathrm{m}}\left(\mathrm{W}_{\mathrm{i}}, \mathrm{X}_{\mathrm{i}}\right)\right)}{\sum_{\mathrm{e} \in \mathrm{E}}\left(\exp \left(\mathrm{v}^{\mathrm{m}}\left(\mathrm{W}_{\mathrm{e}}, \mathrm{X}_{\mathrm{e}}\right)\right)\right)} \text {. }
$$

The supply directed toward establishment i depends on wages and other characteristics of the establishments with type m workers. Normalizing the supply with the supply in establishment $\mathrm{j}$ employing the same type of workers, the model can be written as

$$
\log S_{i}=v^{m}\left(W_{i}, X_{i}\right)-\left[v^{m}\left(W_{j}, X_{j}\right)-\log S_{j}\right]=v^{m}\left(W_{i}, X_{i}\right)+\delta_{m}
$$

where $\delta_{\mathrm{m}}=-\left[\mathrm{v}^{\mathrm{m}}\left(\mathrm{W}_{\mathrm{j}}, \mathrm{X}_{\mathrm{j}}\right)-\ln \mathrm{S}_{\mathrm{j}}\right]$ is equal for all establishments employing workers of similar type.

Even though the observed utility level of being employed at establishment $j$ is higher than at establishment $\mathrm{i}$ for workers of type $\mathrm{m}$, the model implies that some workers will prefer to work at the latter establishment. This is for some random reason $\varepsilon_{\mathrm{e}}^{\mathrm{b}}$ that is unobservable. The aggregation procedure requires only that the deterministic part of the utility function of type $\mathrm{m}$ workers is equal.

At log-linear form in a panel dimension, (4) can be written as

$\mathrm{s}_{\mathrm{it}}=\delta_{\mathrm{i}}+\alpha \mathrm{w}_{\mathrm{it}}+\beta \mathrm{x}_{\mathrm{it}}+\eta_{\mathrm{it}}$,

where subscript $t$ denotes year, lowercase letters denote logarithmic values, $\delta_{i}$ is an establishment-specific constant term, and $\eta$ is the error term. Equation (5) is a simple loglinear estimable model with labor supply elasticity given by $\alpha . \alpha>0$ if the indirect utility function is increasing in $\mathrm{W}$, that is, there is a positive marginal utility of consumption. The wage has a positive effect on labor supply because the establishment becomes more attractive for workers initially working at other establishments. 


\section{The data}

The experimental schools are located in three counties consisting of 89 local governments. All primary and lower secondary public sector schools (first through tenth grade) in these counties are included in the data, ${ }^{5} 565$ schools followed over the six school years $1995-96$ to 2000-01. ${ }^{6}$ Experimental schools exist in 73 percent of the local government districts and are therefore located in many different local labor markets. It is not straightforward to define the borders of local labor markets. However, in the relevant counties the population is to a large extent scattered and relatively few workers reside in a local government district other than the district in which they work, which indicates that the local government districts are not too narrow measures of the local labor market. ${ }^{7}$ School size might be an issue since the population is scattered. In the main part of the paper, I include only schools with at least 20 students on average in the empirical period, ${ }^{8}$ but I will also show that the results are insensitive to this choice.

Table 2 shows the number of schools with a wage premium in the different school years. ${ }^{9}$ Few schools were eligible for a higher wage in the relatively restrictive system in 1996-97 and 1997-98, while about six times as many schools were included in the following years. The changes in the criteria to be included in the system imply that most schools only had a wage premium for a short period. Table 3 shows that out of the 81 experimental schools included in the sample, teachers in 37 schools received a wage premium in only one year during the empirical period. 25 schools have never been IN schools in the empirical period. They were all SIN schools in 1995-96.

Figure 2 illustrates how the classification of IN schools matches the data set available for the present study. Because the criterion is based on lagged teacher shortages, I cannot compare

\footnotetext{
${ }^{5}$ Private schools exist only to a very small degree. In 1995, 0.5 percent of the students in the counties with experimental schools were enrolled at private schools.

${ }^{6}$ Employment data are not available before the school year 1995-96 and some wage flexibility in the hands of the local governments was introduced in the school year 2001-02.

${ }^{7}$ According to the 1990 census, 85 percent of the workers in the relevant counties worked in the local government district in which they resided. Based on the commuting statistics, Statistics Norway has classified 17 different labor markets areas in the relevant counties. There are experimental schools in all these areas, ranging from four to 50 percent of the schools

${ }^{8} 112$ schools have less than 20 students on average, including 70 experimental schools.

${ }^{9} 18$ schools with only one observation in the empirical period (new schools or closed schools) are excluded from the analysis because they provide no information in fixed effects models.
} 
the lagged shortages criterion with the actual classification in the school year 1995-96 and I cannot calculate the four-year average for 1998-99. For the last school years, the classification of IN schools is, with minor exceptions, in accordance with the data. The exceptions may be due to the fact that the state representatives should take errors in lagged data into account in their classification. For the first school years in the sample, in particular 1996-97, there are clearly divergences between the classification of IN schools and the present data. Notice that in these years the classification is based on purpose-specific data collected 1-2 months before the present data. There is a possibility that this allows manipulation of the system by reporting low numbers of certified teachers. However, if anything, the purpose-specific data seem to underreport teacher shortages. There are several schools that seem to be eligible for the wage premium according to the present data, but which did not actually become IN schools. However, it is a concern that the divergence may reflect measurement errors in the present data. For this reason, and because the possibilities to manipulate the system may have changed over time, I will present estimation results for subperiods below.

Table 4 presents descriptive statistics. The experimental schools are relatively small. While the mean size of the experimental schools is 60 students, the mean size of the other schools in the relevant counties is 150 students. This is also reflected in lower teacher supply measured in full-time equivalent employment of certified teachers in the cases when supply is identified. The supply is identified in 62 percent of the nonexperimental schools observations and 85 percent of the experimental schools observations.

In addition to the occurrence of a wage premium, the mean wage level varies across schools because mean teacher experience and amount of formal education vary. The percentage wage premium is calculated based on information of the mean wage level of certified teachers at each school. The average wage premium in the experimental schools is 3.7 percent. However, because only 38 percent of the observations of experimental schools are IN or SIN schools, the average wage premium for those schools is 9.8 percent (about 2,150 NOK per month, or about US\$350). The wage premium ranges from 4.6 percent to 11.9 percent, with the lowest mean in 1995-96 (7.8 percent) and the highest mean in 1998-99 (11.3 percent).

Figure 3 a plots the relationship between changes in the wage premium and changes in teacher supply. It is evident that supply tends to rise when a wage premium is introduced, while 
supply tends to decline when a wage premium is removed. Schools that continue to pay a wage premium have some small changes in the percentage wage premium, mainly because the premium is constant in nominal terms over some years. ${ }^{10}$ Figure $3 \mathrm{~b}$ presents the distribution of the changes in teacher supply when a wage premium is introduced and when a wage premium is removed. The distribution of the former is clearly to the right of the latter. ${ }^{11}$

\section{Estimation results}

Equation (5) can be estimated by the within-school estimator or the first-differenced estimator. Although both methods yield asymptotically consistent estimates for given time dimension under standard assumptions, the former is exactly equal to (5) while the latter is not. Referring to School A in Table 1, the within estimator identifies the effect of wages by comparing average supply in 1993-96 and 1998-2000 (IN school) with average supply in 1997-99 (NIN school). The first-differenced estimator identifies the effect on the switches in 1996-97 and 1998-99. The first-differenced estimator is attractive in the present case because some central arguments for imperfect competition in the labor market are dynamic in nature. On the other hand, there are 'gaps' in the data of observed supply since only observations with excess demand are utilized, and fewer observations are available for the first-differenced estimator since only observations with excess demand in two consecutive years can be utilized.

Table 5 presents the main results. Columns (1)-(4) present results for the within-school estimator while columns (5)-(8) present results for the first-differenced estimator. The main source of variation identifying the labor supply elasticity is whether there is a wage premium or not. The dummy variable for wage premium (IN + SIN school) is significant at one percent level with an effect of 11.0-13.4 percent. The results in columns (1) and (5) imply that, at average percentage wage premium, the elasticity of teacher supply is $1.12-1.37 .^{12}$

\footnotetext{
10 There is also a change in the wage premium if the composition of teachers at a school changes. All observations with a decline of about five percent in the wage premium are from the school year 1996-97. Some schools paid only half of the ordinary wage premium in 1995-96, see Section 3.

${ }^{11}$ The average increase in log teacher supply when wage premium is introduced and removed are 0.15 and -0.08 , respectively. For experimental schools that do not have a wage premium in two years in a row, the corresponding number is -0.03 , while for schools that have a wage premium for two years in a row the number is 0.03 .

${ }^{12}$ Because the nominal wage premium is independent of the initial wage, the percentage wage premium differs across teachers. For newly educated teachers with the lowest qualifications (bachelors), the percentage wage
} 
Columns (2) and (6) in Table 5 investigate whether the response to the wage premium differs between IN and SIN schools. Because only the incumbent teachers receive a wage premium in SIN schools, one would expect the largest response in IN schools. The results show that the difference between IN and SIN schools is small and clearly insignificant.

In columns (3) and (7) in Table 5 the elasticity is estimated directly by including the average percentage wage premium at the school level instead of the dummy variable in the model. The estimated elasticity is larger for the first-differenced estimator (1.35) than for the within estimator (1.05). Columns (4) and (8) indicate that that the within estimator is biased downwards because of missing variables at the school level. Including school-specific time trends, the elasticity increases to 1.43 for the within estimator, while the first-differenced estimator is hardly affected.

The elasticity of school size is about 0.6 and highly significant. Given school-specific factors, it seems like teachers prefer large schools. It is perhaps more likely that large schools have large catchments areas containing both a large number of students and teachers. The result implies that if the number of students increases by 10 percent, teacher supply per student is reduced by 4 percent. Even though there are some economies of scale, excess demand becomes more likely as schools expand. Without any effect of school size, variations in the number of students would have a dramatic impact on the share of certified teachers at a school.

\subsection{Sensitivity analyses}

Because the first-differenced estimator seems more robust across model specifications than the within-school estimator, I only report results for the first-difference estimator in the following. ${ }^{13}$ Table 6 considers several different alternatives to the baseline model formulation, both in terms of new variables and sample.

If the dependent variable includes components of demand, the effect of the wage premium may be underestimated because the demand does not increase with the wage premium. One

premium is largest. Using the centrally decided wage frame, the models in columns (1) and (5) imply that the supply elasticity is in the range $0.77-2.02$.

${ }^{13}$ The results for the within-school estimator are qualitatively similar and are available on request. 
may wonder whether the effect of the number of students has a demand-side explanation. Then the results should to be sensitive to whether school size is included in the model or not. Row (1) in Table 6 shows, however, that the supply elasticity is insensitive to whether the number of students is included in the model. The model in row (2) uses the certified teacherstudent ratio as the dependent variable, neither affecting the estimated supply elasticity.

Rows (3) and (4) in Table 6 introduce some new variables into the model. Bonesrønning et al. (2005) show that both the share of language and ethnic minority students and the share of students with special needs influence teacher supply. They also show that the number of teacher education hours per student (a measure close to the teacher-student ratio), which may be important for teacher effort, has a strong effect on teacher supply. However, including measures of the student body composition or teacher density in the model does not change the estimated supply elasticity.

Another reason why the demand side may affect the dependent variable is that noncertified teachers are utilized to a small degree in some schools. I have assumed observable teacher supply in such schools, but noise might perhaps give observations of noncertified teachers employed in part-time positions in some cases even without excess demand. To test whether such potential misclassification is a problem, row (5) in Table 6 assumes that the supply is only observed when noncertified teachers account for at least one full-time equivalent teacher. This change in sample increases the estimated supply elasticity to 1.6 , which is about one standard error of the baseline model (7) in Table 5.

The present panel data have an unconventional structure since at many schools excess demand is observed in some years but not in other years. The existence of 'gaps' in the data is of specific importance because the first-differenced estimator can utilize information only when there is excess demand in two consecutive years. To shed some light on the importance of gaps in the data, row (6) in Table 6 increases the sample size by using the change in employment of certified teachers, given that supply is observed in year $t$, as the dependent variable instead of the change in supply. Then the estimated supply elasticity increases slightly to 1.45 .

Another feature of the data is that the classification of IN schools is not always in accordance with observed teacher shortages, in particular for the year prior to 1998-99 (see Figure 2). In 
row (7) in Table 6, schools for which the IN school classification is not in accordance with the present data in at least one year are excluded from the sample. This reduces the sample by 10 percent, but does not affect the estimated supply elasticity. A related concern is that measurement error in the dependent variable may be an issue early in the empirical period. In addition, it was in principle easier to manipulate the system in the first years of the empirical period when only teacher shortages lagged one year was the criterion for wage premium. In row (8) the supply elasticity is only identified on the last experimental school system in place, reducing the sample by over 50 percent. In this sample, the within-school variation in the wage premium is markedly reduced, and the effect of the wage is identified only on schools introducing a wage premium. Nevertheless, the estimated supply elasticity does not change much and is highly statistically significant. Figure 4 presents estimates for a moving sample of two years, and they are all in the range 1.2-1.8. These results clearly indicate that gaming of the system is not a relevant issue since this possibility changed markedly during the empirical period. ${ }^{14}$

In difference-in-difference models, lagged residuals of the equation of interest are by construction in the residual of the estimated model. That might bias the effect of the wage premium upwards because eligibility is due to lagged teacher shortages. In particular, mean reversion where a negative shock in supply which makes the school eligible for the wage premium are followed by a positive shock are problematic for the first-differenced estimator. The problem might be smaller for the within-school estimator than for the first-differenced estiamtor, which may explain why the estimated supply elasticity tends to be lower for the former estimator. However, the fact that the estimated supply elasticity in the last system in place, where the criterion for wage premium was based on average teacher shortages the last four years, is similar to the to the estimate for the previous systems where only teacher shortages the previous year count, indicates that this not a major problem for the present analysis. In order to do a more thorough investigation, I have estimated several models excluding the fixed effects.

A simple OLS model at levels on the baseline sample yields a supply elasticity of 0.51 . This is, however, likely to be a downward biased estimate because the wage premium variable are likely to pick up that the school is unattractive in general. We would like to have a continuous

\footnotetext{
${ }^{14}$ The effect of wages seems to be symmetric. When the effects of introducing and removing wage premium are allowed to differ, the elasticity of the former is 1.33 and the elasticity of the latter is 1.36 .
} 
variable of the general attractiveness of the school, but such a variable is not easily constructed. In row (9) in Table 6 the average share of noncertified teachers at the individual school during the empirical period is included in the model. Unattractive schools have high teacher shortages at mean. When including this single variable in the simple OLS model, the estimated elasticity is 1.24 , only slightly lower than for the first-differenced estimator.

An alternative is to use a discontinuity approach, comparing school observations barely eligible for the wage premium with school observations barely ineligible. This is challenging because I have a noisy measure of the eligibility variable early in the empirical period. For the latter period, however, the discontinuity approach is possible to utilize. Row (10) in Table 6 presents the results when only school observations for which teacher shortages are five percentage points above or below the criterion for wage premium are included in the model. ${ }^{15}$ In this case the estimated supply elasticity is 1.91 and significant, although more imprecisely estimated than in models with more observations. ${ }^{16}$

The last rows of Table 6 make different changes to the sample. The estimated elasticity is slightly lower when all Norwegian schools are included in the sample (elasticity of 1.2) despite the fact that it is always variation within schools that identifies the supply elasticity. ${ }^{17}$ When only experimental schools are included, the estimated elasticity is higher (elasticity of 1.8). Rows (13)-(15) investigate the sensitivity to school size. This may be important given that most of the experimental schools are small schools. Including schools with less than 20 students into the analysis increases the estimated supply elasticity, indicating that supply is more elastic at small schools than large schools. The elasticity is clearly higher at schools with less than 50 students than at schools with more than 50 students, although the point estimates are not significantly different at five percent level. ${ }^{18}$

\footnotetext{
${ }^{15}$ The sample includes 35 and 29 observations with and without wage premium, respectively.

${ }^{16}$ The estimated elasticity is not particularly sensitive to the choice of bandwidth. If observations with teacher shortages \pm 3 (7) percentage points around the criterion are included, that is 44 (107) observations, the elasticity is $1.70(1.06)$ and significant at 5 percent level.

${ }^{17}$ The time-specific effects clearly differ in the national sample compared with the sample in Table 5, which has an impact on the estimated supply elasticity probably because the number of IN + SIN schools varies across years.

${ }^{18}$ It appears that the point estimate difference between schools with less and more than 50 students is partly a result of different year-specific effects, although they are not significantly different. Restricting the year effects to be equal across school size, the estimated supply elasticity is 1.68 for small schools and 1.10 for large schools (compared with 1.94 and 0.94 , respectively, in Table 6). The relationship between the supply elasticity and school size can also be investigated by including an interaction term between the number of students and the wage premium. In such a model, however, the interaction term is highly insignificant (t-value of 0.08 ).
} 


\subsection{Selection}

Selection is relevant in the present case because teacher supply is observed only under excess demand. The fixed school effects capture some selection effects, partly because the supply is observed more often in experimental schools than in other schools. However, there is also variation within schools that may bias naïve models that do not take selection into account. Table 4 shows that in experimental schools the supply is more often observed when there is a wage premium than when there is no wage premium, working in the direction of underestimating the supply elasticity when selection is not taken into account.

I will use two approaches to investigate whether selection is important for the estimate of the supply elasticity. The first approach builds on the fact that the experimental schools have recruitment problems in general. In years without excess demand, it is likely that the supply is close to demand. Thus, I simply use employment as the dependent variable, including all observations in the data in the regressions.

The second approach models the selection process. Supply is observed under excess demand, and excess demand is determined by both supply and demand. Thus, selection can be identified utilizing that the demand behavior differs from the determination of supply. Local governments are responsible for the schools and therefore variables at the local government level that influence teacher demand might be valid instruments to identify the selection. ${ }^{19}$ An extensive literature shows that the demand for school expenditures depends on local income. ${ }^{20}$ In addition, different studies have found that the age composition of the population is important for the allocation of resources in multi-purpose authorities, see for example Borge and Rattsø (1995) and Poterba (1997). The instruments I use to identify the selection of schools into excess demand are local government exogenous income per capita and the shares of pre-school children and elderly in the population, included both with current and with lagged values.

\footnotetext{
19 Compulsory education in Norway is the responsibility of multi-purpose local governments providing additional local public services as care of the elderly, day care, and different local utilities.

${ }^{20}$ The local governments have limited possibility to influence their income level. All local governments in Norway have the same income tax rate in a system of income revenue sharing. The second most important revenue is lump sum grants from the central government. Lump sum grants are distributed based on objective criteria, among other things promoting an active regional policy. During the empirical period of the present paper the weight given to different criteria changed. I use the sum of income tax revenue and lump sum grants as exogenous local government income as is traditionally done in Norwegian local public finance studies.
} 
Notice that the second approach has at least two shortcomings. Because the model includes fixed school effects, limited variation over time may make the selection instruments weak. Second, when estimating the selection equation a nonlinear model must be used, while the incidental parameter problem derived by Neyman and Scott (1948) implies that the maximum likelihood estimator of nonlinear fixed effects models in general is inconsistent. ${ }^{21}$

Table 7 shows that replacing supply by employment as the dependent variable, which increases the number of observations by more than 50 percent, hardly affects the estimated coefficients. This indicates that selection is not an important issue. To take better account of teacher demand factors, column (2) includes interactions between year-specific effects and local government-specific effects. These fixed effects difference out all variation at the local government level. The estimated elasticity then increases by one standard error to 1.64. If this is because of demand factors, we would not expect to get the same change in the point estimate when using teacher supply as the dependent variable. However, column (3) in Table 7 shows that for the baseline model, the estimated supply elasticity also increases by about one standard error when year-specific local government fixed effects are included. There seem to be some factors at the local government level that influence the supply elasticity.

The last column in Table 7 shows that the estimated supply elasticity is similar for the full maximum likelihood Heckman (1979) selection model as for the baseline model. In addition, one cannot reject that the correlation between the errors in the selection model and the supply equation is equal to zero, which also indicates that selection is not important in the present case. Notice, however, that the instruments of the selection equation are not particular strong; they are jointly significant only at 2.5 percent level. ${ }^{22}$

\footnotetext{
${ }^{21}$ Some recent papers have proposed different estimators of panel data selection models that overcome the incidental parameter problem. Vella and Verbeek (1999) discuss a random effect approach. The selection equation can be estimated consistently by a probit model if the individual effects $\delta_{\mathrm{i}}$ have a known distribution. This requires that the regressors are uncorrelated with the individual effects, probably not a valid assumption in the present case because the experimental schools are likely to have less favorable locations than other schools. Kyriazidou (1997) discusses the case where the fixed effect selection equation is estimated in a consistent way, for example by a conditional logit model. In this case, non-censored observations similar to censored observations can be used to estimate the supply equation consistently. In the present paper, the supply elasticity is identified by schools in which the teachers have a wage premium in some but not all years, implying that the observations are different by the experiment. Thus, the method proposed by Kyriazidou (1997) can hardly identify the supply elasticity.

${ }^{22}$ The instruments are clearly insignificant if they are included in the equation of interest. When the instruments are included in the model in column (7) in Table 5, the p-value of joint significance is 0.45 . It is a greater concern that the instruments tend not to have the expected sign in the selection equation. The selection equation is available on request.
} 


\subsection{Variation in the supply elasticity across school locations.}

Table 8 presents some crude tests on whether the teacher supply elasticity varies across local labor markets. I use local government boundaries to define the local labor markets. To what extent do increased wages result in new hires being recruited from other schools in the same local labor market? A simple examination is to estimate the effect of the mean wage premium at the local government level, weighted by the number of students. A positive effect of the mean percentage wage premium implies that the number of teachers in the local government increases. The estimated elasticity of the mean wage premium is close to unity and significant at five percent level as shown in column (1) in Table 8, which indicates that schools paying a wage premium to a large extent recruit teachers that previously did not work in a school in the same local government district.

The effect of the mean wage premium captures both the increased supply at schools with a wage premium and the decreased supply at neighboring schools without a wage premium. The model in column (2) in Table 8 disentangles these effects by including wage premium at the school level in the model. To interpret the results, consider first a local government where all students are enrolled at schools with a wage premium of ten percent. The supply increases by 7.66 percent, which is significant at ten percent level. Consider next the case where half of the students in the local government are enrolled at schools in which the teachers receive the wage premium. Then the model implies that the supply decreases by 4.15 percent at schools without a wage premium and increases by 11.81 percent at schools with a wage premium, which implies that the teacher supply elasticity at the local labor market level is 7.66. The latter estimate is independent of the number of schools paying a wage premium and slightly lower than in column (1) in Table 8. The estimate indicates that about 50 percent of the improved supply is at the sacrifice of other schools in the same local government.

The classical example of labor monopsony is an isolated firm in a remote, sparsely populated area. Incumbent workers have high mobility costs and can accept a relatively low wage without quitting and the firm must pay the mobility costs of new hires. Remote firms are faced with less elastic labor supply than other firms. Column (3) in Table 8 reports the results when the baseline model is extended with an interaction term between the percentage wage premium and the log of the number of students in the local government. The interaction term is positive as expected, although insignificant at conventional levels. The effect of the wage premium at level is very close to zero. Excluding that variable, column (4) shows that the 
effect of the interaction term is clearly significant. The results imply that, using the sample variation in the number of students, the supply elasticity varies from 0.8 to 2.1 with a mean of about 1.5. Small local governments seem to have greater problems with recruitment of new teachers than large local governments. This, however, also implies that they have larger potential monopsony power.

\section{Conclusion}

The direct evidence on whether firms have monopsonistic wage-setting power is whether the labor supply faced by the individual establishments is not highly elastic with respect to the wage. Given the problem of identifying good instruments for wages, this paper has argued that utilization of experiments and institutional features are fruitful ways to establish evidence on the elasticity of labor supply directed toward individual establishments. To estimate the elasticity of labor supply, I utilize an experiment in the Norwegian public sector school system in which the variation in wages across schools for identical teachers is solely determined by the central government. In addition, and in contrast to the existing literature on labor supply, I am able to identify the establishments with excess demand. In such establishments, the supply is equal to the actual employment. Using fixed effects models, the average elasticity of labor supply is estimated to be in the range 1.0-1.9. The results also indicate that the elasticity is largest at schools located in densely populated areas in which few other teachers have a wage premium.

The estimated supply elasticity in the present paper is a partial short-run effect. It is a partial effect because schools and school districts cannot influence the wage level. The general equilibrium effect is smaller in the case of wage spillovers. It is a short-run effect because at a large majority of schools, the teachers receive a wage premium only for a limited time period. With expectations of permanent wage premiums, the expected value of the wage premium increases. In addition, higher teacher wage at average would stimulate more students to undertake teacher education. When frictions are present in the labor market, as this study suggests, some wage-setting power lies in the hands of the establishments. However, the possible exploration of monopsony power in the short run must be balanced against long-run considerations when workers can more fully react to wage differentials. 


\section{References}

Boal, W. M. 1995. Testing for employer monopsony in turn-of-the-century coal mining. RAND Journal of Economics 26:519-536.

Boal, W. M., and M. R. Ransom. 1997. Monopsony in the labor market. Journal of Economic Literature 35: 86-112.

Bonesrønning, H., T. Falch and B. Strøm. 2005. Teacher sorting, teacher quality, and student composition', European Economic Review 49:457-483.

Borge, L. E., and J. Rattsø. 1995. Demographic shift, relative costs and the allocation of local public consumption in Norway. Regional Science and Urban Economics 25:705-726.

Boyd, D., H. Lankford and J. Wyckoff. 2005. Explaining the short careers of high-achieving teachers in schools with low-performing students. American Economic Review 95:166-171.

Card, D., and A. B. Krueger. 2000. Minimum wages and employment: A case study of the fast-food industry in New Jersey and Pennsylvania: Reply. American Economic Review 90:1397-1420.

Dickens, R., S. Machin and A. Manning. 1999. The effects of minimum wages on employment: Theory and evidence from Britain. Journal of Labor Economics 17:1-22.

Falch, T., and B. Strøm. 2005. Teacher turnover and non-pecuniary factors. Economics of Education Review 24: 611-631.

Green, F., S. Machin and A. Manning. 1996. The employer size-wage effect: Can dynamic monopsony provide an explanation? Oxford Economic Papers 48:433-455.

Heckman, J. J. 1979. Sample selection bias as a specification error. Econometrica 47:153161.

Kyriazidou, E. 1997. Estimation of a panel data sample selection model. Econometrica 65:1335-1364.

Manning, A. 2003. Monopsony in motion. Imperfect competition in labor markets. Princeton University Press.

McFadden, D. 1974. Conditional logit analysis of qualitative choice behavior. In Frontiers in econometrics, ed. P. Zarembka. New York: Academic Press. 
McFadden, D. 1984. Econometric analysis of qualitative response models. In Handbook of econometrics, ed. Z. Griliches and M. D. Intriligator. Elsevier Science B.V.

Mortensen, D.T. 1986. Job search and labor market analysis. In Handbook of labor economics, ed. O. Ashenfelter and R. Layard. Amsterdam: Elsevier Science B.V.

Nelson, P. 1973. The elasticity of labor supply to the individual firm. Econometrica 41:853866.

Neumark, D., and W. Wascher. 2000. Minimum wages and employment: A case study of the fast-food industry in New Jersey and Pennsylvania: Comment. American Economic Review 90:1362-1396.

Neyman, J., and E. L. Scott. 1948. Consistent estimation from partially consistent observations. Econometrica 16:1-32.

Poterba, J. 1997. Demographic structure and the political economy of public education. Journal of Policy Analysis and Management. 16:48-66.

Ransom, M. R., and D. P. Sims 2008. Estimating the firm's labor supply curve in a "new monopsony" framework: School teachers in Missouri. Working Paper.

Staiger, D., J. Spetz and C. Phibbs. 1999. Is there monopsony in the labor market? Evidence from a natural experiment. NBER Working Paper 7258.

Sullivan, D. 1989. Monopsony power in the market for nurses. Journal of Law \& Economics 32:S135-S178.

Vella, F., and M. Verbeek. 1999. Two-step estimation of panel data models with censored endogenous variables and selection bias. Journal of Econometrics 90:239-263. 
Table 1. Possible states of the experimental schools

\begin{tabular}{lcc}
\hline School year & School A & School B \\
\hline $1993-1994$ & IN & IN \\
$1994-1995$ & IN & SIN \\
$1995-1996$ & IN & SIN \\
\hline $1996-1997$ & NIN & NIN \\
$1997-1998$ & NIN & NIN \\
\hline $1998-1999$ & IN & NIN \\
$1999-2000$ & IN & IN \\
$2000-2001$ & SIN & SIN
\end{tabular}

Note: IN denotes that all certified teachers at the school receive a wage premium, SIN denotes that only the incumbent certified teachers at the school receive a wage premium, and NIN denotes that none of the teachers receive a wage premium.

Table 2. The number of experimental schools in different states

\begin{tabular}{lcccccc}
\hline & $1995-96$ & $1996-97$ & $1997-98$ & $1998-99$ & $1999-2000$ & $2000-01$ \\
\hline IN & 13 & 5 & 4 & 26 & 32 & 29 \\
SIN & 37 & 0 & 5 & 0 & 8 & 19 \\
IN+SIN & 50 & 5 & 9 & 26 & 40 & 48
\end{tabular}

Note: IN denotes that all certified teachers at the school receive a wage premium and SIN denotes that only the incumbent certified teachers at the school receive a wage premium.

Table 3. The number of experimental schools in years of different states

\begin{tabular}{lccccccc}
\hline & 0 years & 1 year & 2 years & 3 years & 4 years & 5 years & 6 years \\
\hline IN & 25 & 24 & 16 & 11 & 5 & 0 & 0 \\
SIN & 25 & 46 & 10 & 1 & 0 & 0 & 0 \\
NIN & 1 & 5 & 12 & 17 & 12 & 34 & 0 \\
IN + SIN & 0 & 36 & 13 & 17 & 11 & 3 & 1 \\
\hline \hline
\end{tabular}

Note: IN denotes that all certified teachers at the school receive a wage premium, SIN denotes that only the incumbent certified teachers at the school receive a wage premium, and NIN denotes that none of the teachers receive a wage premium. 
Table 4. Descriptive statistics, mean values (standard deviation)

\begin{tabular}{lccc}
\hline Sample & $\begin{array}{c}\text { Nonexperimental } \\
\text { schools }\end{array}$ & $\begin{array}{c}\text { Experimental } \\
\text { schools }\end{array}$ & $\begin{array}{c}\text { IN and SIN } \\
\text { schools }\end{array}$ \\
\hline Number of students & $151.1(115.2)$ & $60.7(43.2)$ & $58.5(47.2)$ \\
Teacher supply in the cases of excess demand & $14.7(9.5)$ & $7.4(4.7)$ & $7.4(5.1)$ \\
Population & $15,007(17,103)$ & $5,741(8,618)$ & $6,008(9,782)$ \\
IN & 0 & 0.229 & 0.612 \\
SIN & 0 & 0.145 & 0.388 \\
Percentage wage premium & 0 & $0.037(0.049)$ & $0.098(0.018)$ \\
Observations & & 476 & 178 \\
Percentage of noncensored observations & 2066 & 84.9 & 78.7 \\
\hline \hline
\end{tabular}

Table 5. Estimated labor supply elasticity. Dependent variable is log teacher supply

\begin{tabular}{|c|c|c|c|c|c|c|c|c|}
\hline & (1) & (2) & (3) & (4) & (5) & (6) & (7) & (8) \\
\hline & \multicolumn{4}{|c|}{ Within-school estimator } & \multicolumn{4}{|c|}{ First-differenced estimator } \\
\hline $\begin{array}{l}\text { Wage premium at school } \\
\text { (IN + SIN school) }\end{array}$ & $\begin{array}{c}0.110 \\
(0.026)\end{array}$ & $\begin{array}{c}0.121 \\
(0.033)\end{array}$ & - & - & $\begin{array}{c}0.134 \\
(0.028)\end{array}$ & $\begin{array}{c}0.127 \\
(0.039)\end{array}$ & - & - \\
\hline IN school & - & $\begin{array}{l}-0.019 \\
(0.034)\end{array}$ & - & - & - & $\begin{array}{c}0.011 \\
(0.024)\end{array}$ & - & - \\
\hline Percentage wage premium & - & - & $\begin{array}{c}1.047 \\
(0.278)\end{array}$ & $\begin{array}{c}1.431 \\
(0.394)\end{array}$ & - & - & $\begin{array}{c}1.353 \\
(0.281)\end{array}$ & $\begin{array}{c}1.309 \\
(0.332)\end{array}$ \\
\hline $\log$ (Number of students) & $\begin{array}{c}0.625 \\
(0.055)\end{array}$ & $\begin{array}{c}0.625 \\
(0.054)\end{array}$ & $\begin{array}{c}0.628 \\
(0.054)\end{array}$ & $\begin{array}{c}0.567 \\
(0.076)\end{array}$ & $\begin{array}{c}0.575 \\
(0.059)\end{array}$ & $\begin{array}{c}0.576 \\
(0.059)\end{array}$ & $\begin{array}{c}0.575 \\
(0.059)\end{array}$ & $\begin{array}{c}0.549 \\
(0.075)\end{array}$ \\
\hline School-specific trend & No & No & No & Yes & No & No & No & Yes \\
\hline Standard error of equation & 0.1587 & 0.1587 & 0.1589 & 0.1407 & 0.1896 & 0.1897 & 0.1896 & 0.2086 \\
\hline Observations & 1,680 & 1,680 & 1,680 & 1,680 & 1,091 & 1,091 & 1,091 & 1,091 \\
\hline
\end{tabular}

Note: Year-specific effects included. Standard errors corrected for within-school clustering in parentheses. 
Table 6. Sensitivity analyses. Dependent variable is log of teacher supply, first-differenced estimator

\begin{tabular}{|c|c|c|c|c|}
\hline & \multicolumn{2}{|c|}{ Specification changes compared to the model in column (7) in Table 5} & \multirow{2}{*}{$\begin{array}{l}\text { Obser- } \\
\text { vations }\end{array}$} & \multirow{2}{*}{$\begin{array}{l}\text { Estimated } \\
\text { elasticity } \\
\text { (St. error) }\end{array}$} \\
\hline & Equation & Sample & & \\
\hline$(1)$ & $\log$ (Number of students) excluded & None & 1,091 & $\begin{array}{c}1.377 \\
(0.275)\end{array}$ \\
\hline (2) & $\begin{array}{l}\text { The effect of } \log (\text { Number of students) } \\
\text { restricted to unity }\end{array}$ & None & 1,091 & $\begin{array}{l}1.335 \\
(0.293)\end{array}$ \\
\hline (3) & $\begin{array}{l}\text { The share of students from ethnic } \\
\text { minorities and the share of students with } \\
\text { special needs included }\end{array}$ & None & 1,082 & $\begin{array}{c}1.346 \\
(0.281)\end{array}$ \\
\hline (4) & $\begin{array}{l}\log (\text { Number of students) and } \log (\text { Teacher } \\
\text { education hours) included at squared, cubic } \\
\text { and differenced form }\end{array}$ & None & 1,085 & $\begin{array}{l}1.323 \\
(0.278)\end{array}$ \\
\hline$(5)$ & None & $\begin{array}{l}\text { Only observations with at least one } \\
\text { full-time equivalent noncertified teacher } \\
\text { are regarded as noncensored }\end{array}$ & 641 & $\begin{array}{l}1.615 \\
(0.356)\end{array}$ \\
\hline (6) & $\begin{array}{l}\text { Using } s_{i t}-e_{i t-1} \text { as dependent variable } \\
\text { instead of } s_{i t}-s_{i t-1} \text {, where e is employment }\end{array}$ & $\begin{array}{l}\text { Increasing because more observations } \\
\text { of the dependent variable }\end{array}$ & 1,413 & $\begin{array}{l}1.449 \\
(0.279)\end{array}$ \\
\hline (7) & None & $\begin{array}{l}\text { Excluding schools for which IN } \\
\text { classification is not in accordance with } \\
\text { the present data at least one year }\end{array}$ & 974 & $\begin{array}{l}1.335 \\
(0.393)\end{array}$ \\
\hline (8) & None & Only the period $1999-2000$ to $2000-01$ & 472 & $\begin{array}{l}1.443 \\
(0.497)\end{array}$ \\
\hline (9) & $\begin{array}{l}\text { OLS at level without fixed effects, but } \\
\text { including the variable mean teacher } \\
\text { shortages during the empirical period }\end{array}$ & $\begin{array}{l}\text { Increasing because more observations } \\
\text { of the dependent variable }\end{array}$ & 1,680 & $\begin{array}{l}1.242 \\
(0.324)\end{array}$ \\
\hline$(10)$ & OLS at level without fixed effects & $\begin{array}{l}\text { Only schools with shortages } \pm 5 \% \\
\text { points around the criterion for wage } \\
\text { premium, } 1999-2000 \text { to } 2000-01\end{array}$ & 64 & $\begin{array}{c}1.681 \\
(0.676)\end{array}$ \\
\hline (11) & None & All Norwegian schools & 5,849 & $\begin{array}{c}1.197 \\
(0.281)\end{array}$ \\
\hline$(12)$ & None & Only experimental schools & 298 & $\begin{array}{c}1.766 \\
(0.305)\end{array}$ \\
\hline (13) & None & $\begin{array}{l}\text { Including schools with less than } 20 \\
\text { students on average }\end{array}$ & 1,297 & $\begin{array}{l}1.528 \\
(0.290)\end{array}$ \\
\hline (14) & None & $\begin{array}{l}\text { Schools with average number of } \\
\text { students }<50\end{array}$ & 490 & $\begin{array}{l}1.935 \\
(0.388)\end{array}$ \\
\hline$(15)$ & None & $\begin{array}{l}\text { Schools with average number of } \\
\text { students } \geq 50\end{array}$ & 807 & $\begin{array}{c}0.943 \\
(0.340)\end{array}$ \\
\hline
\end{tabular}

Note: Standard errors corrected for within-school clustering in parentheses. 
Table 7. Estimated supply elasticity and selection.

\begin{tabular}{|c|c|c|c|c|}
\hline \multirow{3}{*}{$\frac{\text { Method }}{\text { Dependent variable }(\log )}$} & $(1)$ & $(2)$ & (3) & \multirow{3}{*}{$\begin{array}{c}(4) \\
\text { Selection } \\
\text { Supply }\end{array}$} \\
\hline & \multicolumn{3}{|c|}{ First-differenced estimator } & \\
\hline & Employment & Employment & Supply & \\
\hline Percentage wage premium & $\begin{array}{l}1.325 \\
(0.265)\end{array}$ & $\begin{array}{l}1.637 \\
(0.304)\end{array}$ & $\begin{array}{l}1.759 \\
(0.341)\end{array}$ & $\begin{array}{l}1.425 \\
(0.283)\end{array}$ \\
\hline $\log$ (Number of students) & $\begin{array}{c}0.585 \\
(0.043)\end{array}$ & $\begin{array}{c}0.612 \\
(0.045)\end{array}$ & $\begin{array}{c}0.562 \\
(0.075)\end{array}$ & $\begin{array}{c}0.564 \\
(0.060)\end{array}$ \\
\hline Year - Local government interaction & No & Yes & Yes & No \\
\hline Standard error of equation & 0.1840 & 0.1758 & 0.1872 & 0.1905 \\
\hline Observations & 2,106 & 2,106 & 1,091 & 2,106 \\
\hline Noncensored observations & 2,106 & 2,106 & 1,091 & 1,091 \\
\hline $\begin{array}{l}\text { F-test for joint significance of the instruments } \\
\text { in the probit selection equation, } p \text {-value }\end{array}$ & - & - & - & 0.025 \\
\hline $\begin{array}{l}\text { Wald test for independence of the selection } \\
\text { and supply equations, } p \text {-value }\end{array}$ & - & - & - & 0.361 \\
\hline
\end{tabular}

Note: Year-specific effects included. Standard errors corrected for within-school clustering in parentheses.

Table 8. Nonconstant labor supply elasticity. Dependent variable is log teacher supply

\begin{tabular}{|c|c|c|c|c|}
\hline & (1) & $(2)$ & (3) & (4) \\
\hline Percentage wage premium & - & $\begin{array}{c}1.596 \\
(0.342)\end{array}$ & $\begin{array}{c}-0.029 \\
(1.659)\end{array}$ & - \\
\hline $\begin{array}{l}\text { Weighted mean percentage wage premium } \\
\text { in the local government district }\end{array}$ & $\begin{array}{c}0.991 \\
(0.488)\end{array}$ & $\begin{array}{l}-0.830 \\
(0.549)\end{array}$ & - & - \\
\hline $\begin{array}{l}\text { (Percentage wage premium }) * \log (\text { number of } \\
\text { students in the local government })\end{array}$ & - & - & $\begin{array}{c}0.232 \\
(0.279)\end{array}$ & $\begin{array}{c}0.227 \\
(0.047)\end{array}$ \\
\hline $\log$ (Number of students) & $\begin{array}{c}0.578 \\
(0.060)\end{array}$ & $\begin{array}{c}0.574 \\
(0.060)\end{array}$ & $\begin{array}{c}0.576 \\
(0.059)\end{array}$ & $\begin{array}{c}0.576 \\
(0.059)\end{array}$ \\
\hline $\log ($ Number of students in the local government) & - & - & $\begin{array}{c}0.003 \\
(0.092)\end{array}$ & $\begin{array}{c}0.003 \\
(0.092)\end{array}$ \\
\hline Standard error of equation & 0.1923 & 0.1895 & 0.1896 & 0.1895 \\
\hline Observations & 1,091 & 1,091 & 1,091 & 1,091 \\
\hline
\end{tabular}

Note: All models estimated by the first-difference estimator. Year-specific effects included. Standard errors corrected for within-school clustering in parentheses. 
Figure 1. Identification of teacher supply

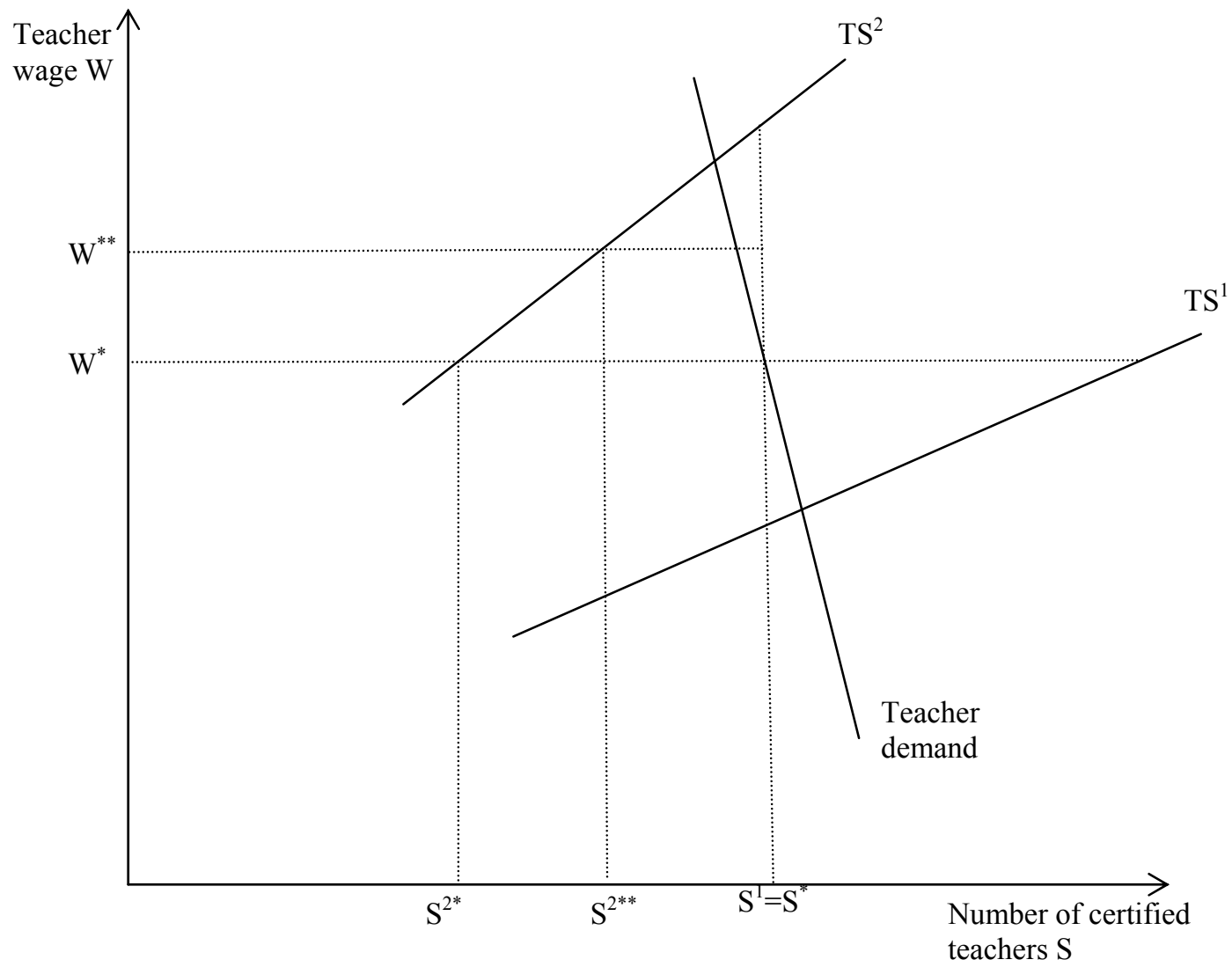


Figure 2. The criterion for being IN school and observed teacher shortages

a) $1996-97$ and $1997-98$

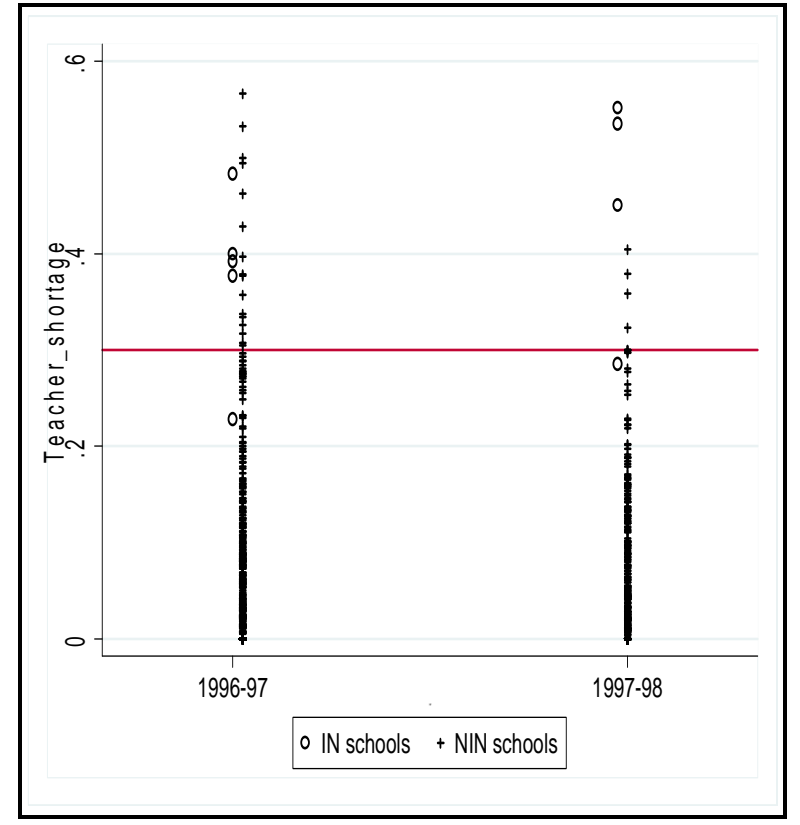

b) $1999-2000$ and $2000-01$

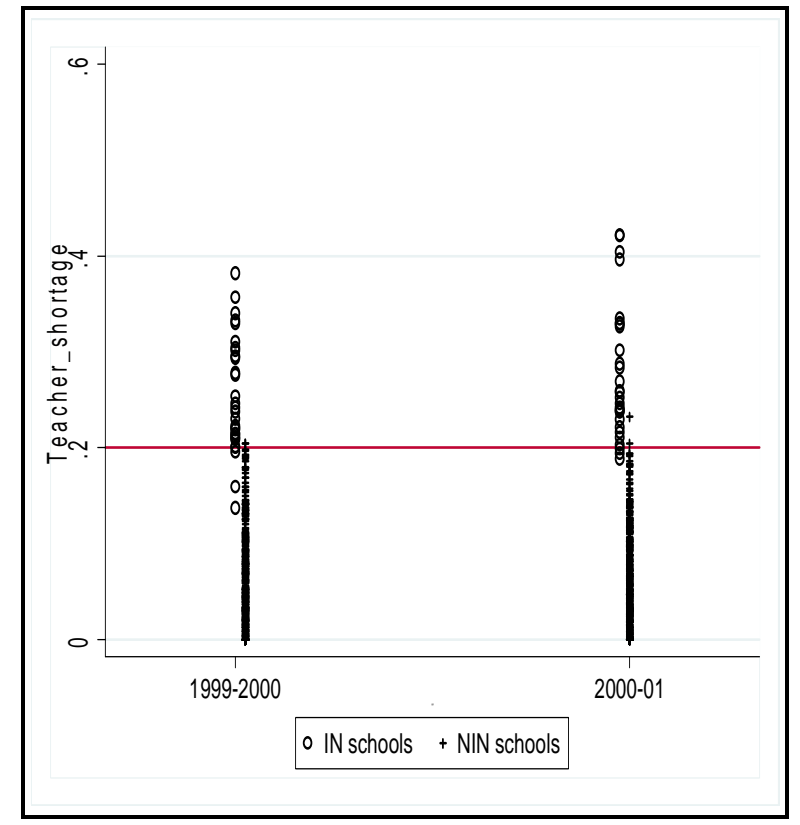

Figure 3. Teacher supply and wage premium, experimental schools

a) Changes in supply and wage premium

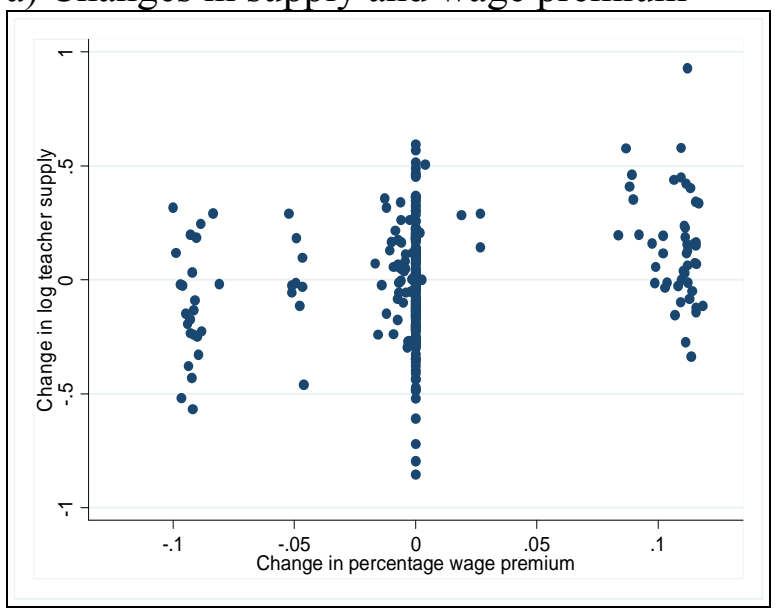

b) Density of the change in log teacher supply

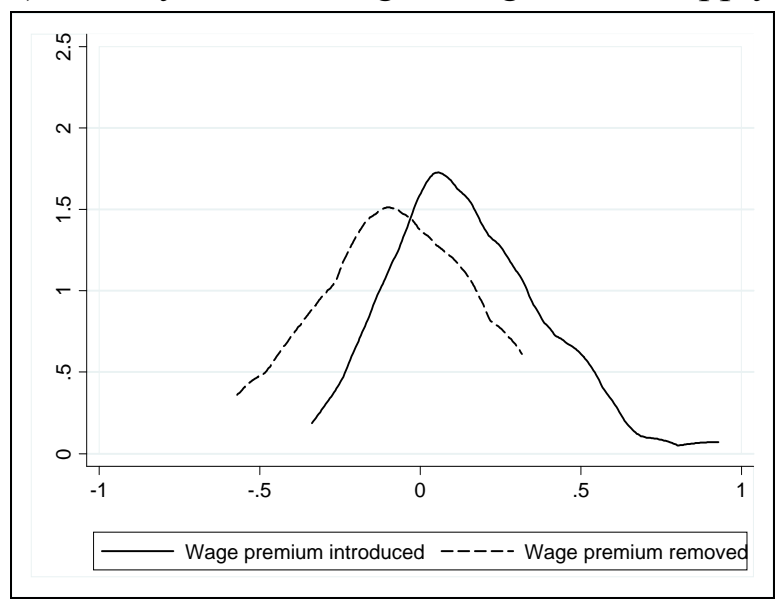


Figure 4. Time-varying teacher supply elasticities \pm 2 standard errors

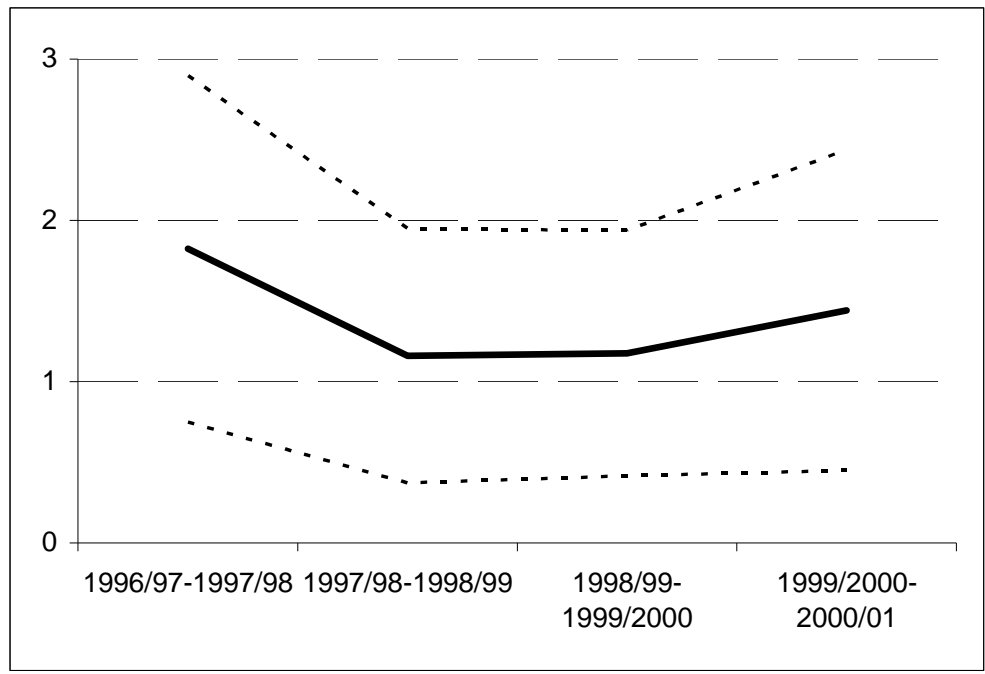

